\title{
THE PACIFIC EXPOSITION 2019 \\ IMPLEMENTASI KEBIJAKAN LUAR NEGERI INDONESIA DALAM \\ PENDEKATANNYA DENGAN KAWASAN PASIFIK
}

\author{
Prasetia Anugrah Pratama \\ Yohanes Sulaiman
}

Ilmu Hubungan Internasional, Fakultas Ilmu Sosial dan Ilmu Politik

Universitas Jenderal Achmad Yani

\begin{abstract}
Abstrak
Masalah keamanan di Papua Barat terus mendapatkan perhatian dari negara-negara lain. Indonesia yang bertindak untuk mempertahankan kedaulatannya di tanah Papua, dikecam sebagai pelanggar hak asasi penduduk Papua Barat, terutama oleh negara-negara di kawasan Pasifik. Sorotan ini menyebabkan Pemerintah Indonesia mengambil kebijakan untuk melaksanakan Pacific Exposition 2019 sebagai salah satu cara untuk memperbaiki citra Indonesia di kawasan Pasific. Artikel ini akan menjelaskan mengapa biro di birokrasi Indonesia membentuk kebijakan luar negeri dengan cepat dan dapat memperlihatkan reaksi dan mengambil langkah-langkah antisipasi yang diperlukan negara, terutama dibandingkan dengan menunggu persamaan pandangan dengan opini-opini masyarakat untuk menyelesaikan masalah yang sudah ada.
\end{abstract}

Kata Kunci: Birokrasi, Kebijakan Luar Negeri, Pembuatan Kebijakan, Opini Publik.

\begin{abstract}
The domestic problems concerning West Papua faced by the Indonesian government, never stop to attract the attention of other countries. Indonesia, which acts to maintain the integrity of its sovereignty, is considered to have violated the human rights of the people of West Papua by the countries of the Pacific region. Critical actions related to alleged human rights violations in West Papua led the Indonesian Government to establish foreign policy to conduct diplomacy and propose holding the 2019 Pacific Exposition as a way to improve Indonesia's image in the Pacific region. This paper, will explain why the bureau in Indonesia's political bureaucracy produces foreign policy with a faster process, and can show a reaction and anticipatory steps needed by the state. Especially when compared to waiting for conformity with the opinions provided by the public in overcoming existing problems.
\end{abstract}

Key Words: Bureaucratic, Foreign Policy, Policy Making, Public Opinion. 


\section{PENDAHULUAN}

Hubungan antara Indonesia dengan negara-negara di kawasan pasifik bisa dianggap sebagai hubungan yang belum berjalan harmonis dan seia sekata dalam persepsinya mengenai suatu permasalahan. Berbatasan langsung di wilayah timur dengan Papua Nugini dan Samudera Pasifik nyatanya tidak memberi kemudahan bagi Indonesia untuk berinteraksi dengan negara-negara tersebut. Salah satu permasalahan yang membuat hubungan antara Indonesia dan Pasifik belakangan ini memiliki tensi tinggi, merupakan akibat dari meningkatnya kekhawatiran negaranegara kawasan tersebut tentang kasus pelanggaran Hak Asasi Manusia (HAM) yang dilakukan oleh Indonesia di Papua Barat ${ }^{1}$. Vanuatu dan Kepulauan Solomon telah mengambil langkah yang signifikan dengan mengangkat isu ini pada pertemuan Dewan HAM Persatuan Bangsa-bangsa (PBB) di Jenewa, Swiss ${ }^{2}$. Selain kedua negara tersebut di kesempaatan berbeda negara Selandia Baru juga menyuarakan kekhawatiran mereka melalui Menteri Luar Negeri (Menlu) Winston Peters, yang menyebut bahwa negara mereka akan meningkatkan perhatiannya terhadap isu kemanusiaan di Papua ${ }^{3}$, langkah perwakilan negara pasifik tersebut tentu menjadi sinyal jelas yang mengharuskan Indonesia untuk membuat kebijakan luar negeri yang komprehensif (dapat diterima) oleh kawasan Pasifik.

Menanggapi hal tersebut, Indonesia bereaksi dengan merumuskan kebijakan luar negeri untuk mendorong diadakannya pameran bisnis dan perdagangan pada pertengahan Juli 2019 yang bertempat di Auckland, Selandia Baru. Pameran yang diberi nama The Pacific Exposition 2019 (Eksposisi Pasifik

\footnotetext{
${ }^{1}$ Abraham Utama, "Pemerintah Indonesia 'tak bisa' cegah negara Pasifik angkat isu Papua di PBB", BBC.com, diakses dari https://www.bbc.com/indonesia/indonesia-41764268, pada tanggal 1 Januari 2020 pukul. 15.23 WIB.

2 Dea, "Vanuatu dan Kepulauan Solomon Bawa Isu Papua ke Dewan HAM PBB", CNN Indonesia.com, diakses dari https://www.cnnindonesia.com/internasional/20190918150338-113-431611/vanuatu-dankepulauan-solomon-bawa-isu-papua-ke-dewan-ham-pbb, pada tanggal 1 Januari 2020 pukul. 15.36 WIB.

${ }^{3}$ Mackenzie Smith \& Johnny Blades, "Indonesia to make major Pacific pitch at NZ expo", RNZ.co.nz, diakses dari https://www.rnz.co.nz/international/pacificnews/393325/indonesia-to-make-major-pacific-pitch-at-nz-expo, pada tanggal 1 Januari 2020 pukul. 17.28 WIB.
} 
2019) ${ }^{4}$ dianggap bukan hanya memiliki agenda ekonomi didalamnya, namun juga bermuatan politik ${ }^{5}$ karena menjadi forum pertemuan antara Menlu Indonesia, Selandia Baru, Australia, serta pejabat pemerintah senior dari seluruh negara Polinesia dan Melanesia. Tujuan utamanya jelas untuk mendorong hubungan diplomatik yang lebih baik antara Indonesia dan negara-negara dari kawasan Pasifik tersebut. Apakah yang menjadi pertimbangan birokrat / aktor yang memiliki peran dalam birokrasi Indonesia untuk menetapkan kebijakan tersebut dan mengapa kebijakan luar negeri ini dianggap sebagai solusi untuk mengatasi permasalahan tersebut? Apakah Teori birokrasi Allison yang meyakini bahwa birokrat memiliki peranan penting dalam pengambilan kebijakan luar negeri ini yang memang benar adanya atau justru kebijakan luar negeri ini hanyalah sebuah aksi politik yang dilakukan untuk memenuhi tuntutan komunitas kebijakan / publik seperti keyakinan Walt?.

Penulis memiliki argumen bahwa kebijakan luar negeri ini merupakan keputusan yang diambil oleh Kementerian Luar Negeri Indonesia yang menjadi biro dalam birokrasi politik yang ada, sebagai pilihan yang harus dilakukan dalam rangka menangani tekanan dari publik baik didalam maupun luar negeri mengenai isu kemanusiaan di Papua. Penulis juga melihat bahwa langkah Indonesia untuk membentuk The Pacific Exposition 2019 sebagai badan baru, merupakan langkah yang membawa perkembangan baik bagi Indonesia dalam upaya untuk memperbaiki citra. Namun, implementasi dari kebijakan luar negeri melalui pameran ini menurut penulis bukanlah suatu cara yang dengan serta merta dapat menyelesaikan ketegangan yang timbul antara Indonesia dan negara-negara kawasan Pasifik.

Tulisan ini menggunakan dua teori yaitu teori birokrasi politik yang diutarakan oleh Graham Allison dan teori komunitas kebijakan yang juga merujuk kepada opini publik yang dipopulerkan oleh Stephen Walt untuk sekaligus memperbandingkan teori mana yang sebenarnya lebih baik untuk digunakan dalam

4 __, "Home", Pacific Exposition 2019 Official Website, RNZ.co.nz, diakses dari http://pacificexposition.co.nz/, pada tanggal 1 Januari 2020 pukul. 18.59 WIB.

${ }^{5}$ Mackenzie Smith \& Johnny Blades, Op Cit. Ibid. 
menganalisa proses pengambilan kebijakan luar negeri Indonesia tersebut. Penulis akan berfokus kepada level analisa negara, dimana struktur birokrasi dan opini publik Indonesia menjadi pertimbangan para aktor yang terlibat dalam merumuskan kebijakan. Dengan tujuan untuk menjawab pertanyaan penelitian yang diuraikan sebelumnya, mencari justifikasi dari pengambilan kebijakan luar negeri Indonesia yang tentunya merupakan refleksi dari orientasi negara tersebut dalam interaksi secara regional maupun global ${ }^{6}$, sekaligus menganalisa kesesuaian kebijakan tersebut dengan proyeksi kebijakan luar negeri yang disampaikan oleh Menteri Luar Negeri Indonesia Retno Marsudi yaitu formula 4+1 khususnya poin yang menyatakan keseriusan Indonesia meningkatkan peran Indonesia dalam hubungan internasional ${ }^{7}$.

\section{PEMBAHASAN}

\section{A. Teori Birokrasi Politik}

Teori ini merupakan teori yang berkeyakinan bahwa suatu kebijakan merupakan hasil dari proses tawar-menawar di dalam channel / saluran yang diatur di antara para aktor yang diposisikan secara hierarkis dalam pemerintahan. Dalam Birokrasi politik aktor yang memilki kepentingan tidaklah menjadi satu kesatuan akan tetapi terpecah. Aktor-aktor politik dalam pandangan Allison akan bereaksi sesuai dengan kepentingan pribadi mereka maupun kepentingan yang sifatnya hanya menguntungkan bagi biro (organisasi / kesatuan) dimana aktor tersebut berada dalam hal ini aktor aktor tersebut ialah presiden, menteri dan kementeriannya. Dalam pandangannya Alisson mempercayai bahwa struktur intranasional (dalam pemerintahan suatu negara) merupakan suatu arena yang kompleks (rumit) dan hal tersebut membuat keleluasaan yang diperoleh dari pembagian

\footnotetext{
${ }^{6}$ Stephen Martin Walt, "Hell of Good Intention, America Foreign Policy Elite and the Decline of U.S. Primacy", Farrar, Straus, and Giroux, New York.

7 _ "Indonesian FM Presents the Diplomacy Priorities 2019-2024 to the House of Representatives", Ministry of Foreign Affairs of the Republic of Indonesia, diakses dari https://kemlu.go.id/portal/en/read/786/berita/indonesian-fm-presents-the-diplomacypriorities-2019-2024-to-the-house-of-representatives, pada tanggal 1 Januari 2019 pukul. 23.12 WIB.
} 
kekuasaan memang diperlukan untuk menjamin bahwa setiap aktornya memiliki keleluasaan dalam proses pembuatan kebijakan ${ }^{8}$.

Dalam birokrasi Allison menganggap bahwa posisi Presiden atau pemimpin tertinggi dari negara tidak lebih dari suatu kekuatan istimewa yang berada di antara banyak kekuatan lainnya yang meskipun lebih kecil tetapi memiliki pengaruh yang cukup besar, Alisson menyebutnya dengan konsep Chief \& Indians ${ }^{9}$. Perbedaan kekuatan tersebutlah yang pada akhirnya menimbulkan kecenderungan para birokrat / Indians yang memiliki kekuatan kecil, berlomba mendekati pemimpin / Chief mereka dengan tujuan untuk dapat memberikan pengaruh yang lebih besar terhadap setiap kebijakan yang akan diambil. Dalam teorinya Allison menganggap bahwa setiap aktor akan memiliki minat yang berbeda dan persaingan yang ada akan membuat aktor tersebut menjadi tidak fokus pada masalah strategis secara $\operatorname{total}^{10}$ sehingga mendorong mereka untuk membuat keputusan yang reaktif dan cepat yang terkadang tidak menyelesaikan permasalahan yang dihadapi.

\section{B. Teori Komunitas Kebijakan (Opini Publik)}

Teori yang disusun oleh Stephen Walt ini menjelaskan mengenai peran masyarakat yang memengaruhi keputusan pemerintahan. Dalam teori ini Stephen Walt meyakini bahwa demokrasi jelas memiliki keunggulan jika dibandingkan dengan kediktatoran. Demokrasi yang memberikan kebebasan kepada publik untuk berpartisipasi dan mengutarakan pendapat mereka akan memberikan efek dorongan terhadap para pemimpin maupun aktor yang memiliki kekuasaan untuk bertanggung jawab kepada publik vis a vis dengan ketakutan yang aktor tersebut milliki akan sanksi pemilihan. Kekhawatiran tersebut yang menurut walt menjadi sesuatu yang mendisiplinkan pelaksanaan kekuasaan dan mendorong para penguasa untuk menunjuk bawahan yang efektif ${ }^{11}$.

\footnotetext{
${ }^{8}$ Graham T Allison, "Conceptual Models and 'The Cuban Missile Crisis"', The American Political Science Review, VOL. LXIII, Cambridge University Press, Cambridge, 1969. Hlm. 707.

${ }^{9}$ Ibid, Hlm 709.

${ }^{10}$ Ibid, Hlm 710.

${ }^{11}$ Stephen Martin Walt, Op Cit, Ibid.
} 
Walt memaparkan bahwa demokrasi juga akan mendorong timbulnya pasar ide karena kebebasan yang didapat oleh warga negara atau masyarakat lainnya terhadap akses informasi akan memberikan mereka keleluasaan dalam memberikan pendapat. Pendapat yang muncul dari masyarakat tersebutlah yang nantinya akan melalui perdebatan dan menyaring ide-ide buruk sehingga memungkinkan alternatif kebijakan yang lebih baik muncul. Senada dengan keyakinan Allison, Walt juga menyampaikan bahwa birokrasi urusan luar negeri secara tidak langsung akan melemahkan akuntabilitas dan menyulitkan proses check and balance. Kedua hal tersebut menjadi penting karena dari dua hal tersebutlah bisa ditentukan siapa sebenarnya yang memiliki tanggung jawab atas pencapaian yang diraih dan kegagalan yang dihadapi dari kebijakan yang diambil. Apakah itu murni kebiijakan yang diambil oleh pemerintah atau sebuah kebijakan yang terbentuk dari berbagai pendapat yang disampaikan oleh komunitas kebijakan baik itu Organisasi, tim pemikir (think tank), media, atau kelompok kepentingan yang tentu mewakili opini publik $^{12}$.

Dari paparan tersebut penulis melihat bahwa kedua teori ini memiliki keterkaitan satu sama lain yang pada akhirnya memberikan pengaruh terhadap perumusan kebijakan luar negeri. Penulis akan melakukan perbandingan antara kedua teori tersebut dalam paper ini, sekaligus mengulas kebijakan luar negeri Indonesia terhadap kawasan Pasifik yang telah ditetapkan dan diimplementasikan melalui The Pacific Exposition 2019. Untuk menemukan teori manakah yang sebenarnya memiliki pengaruh lebih besar terhadap pengambilan kebijakan politik luar negeri tersebut, teori birokrasi politik yang diperkenalkan oleh Allison atau bentuk opini publik yang disampaikan melalui apa yang disebut Walt sebagai komunitas kebijakan.

${ }^{12}$ Ibid. 


\section{Orientasi Politik Luar Negeri Indonesia dan Pentingnya Kawasan Pasifik}

Orientasi Politik Luar Negeri bebas aktif Indonesia merupakan suatu prinsip yang terus mengalami proses penafsiran kembali seiring perkembangan jaman. Namun, orientasi ini tetap konsisten ${ }^{13}$ menjadi dasar dari pelaksanaan politik luar negeri Indonesia untuk berperan sebagai subjek dari hubungan internasional ${ }^{14}$. Politik luar negeri Indonesia tentu akan disesuaikan dengan kepentingan nasional Indonesia, dan bebas aktif membuat Indonesia tidak memiliki batasan untuk bekerjasama serta menjalin hubungan dengan negara-negara lain yang dianggap sebagai mitra yang sesuai dengan kepentingan nasional Indonesia. berbicara mengenai kepentingan nasional Indonesia ini tentu menarik ketika dianalisa menggunakan model politik birokrasi yang tidak melihat aktor yang menyatu tetapi lebih banyak aktor yang memiliki peran dalam perumusan kebijakan ${ }^{15}$, dalam hal ini berarti menyangkut Presiden, Menteri luar negeri, Kementerian luar negeri, Direktorat jenderal Kawasan Asia Pasifik dan Afrika (ASPASAF), Direktur Jenderal ASPASAF, serta unit kerja ASPASAF di dalam kementerian tersebut. Struktur tersebut juga menurut penulis beririsan pula dengan keyakinan Walt bahwa Komunitas kebijakan luar negeri dimulai dengan individu dan lembaga pemerintah yang ditugasi menangani berbagai aspek hubungan luar negeri ${ }^{16}$, menarik karena tugas tersebut merupakan tugas dari aktor-aktor yang telah disebutkan sebelumnya dan memang terdiri dari individu dan lembaga pemerintah.

Direktorat Jenderal ASPASAF kementerian luar negeri Indonesia telah dengan jelas mengakui pentingnya diplomasi yang baik dengan negara-negara dari kawasan Pasifik, unit kerja tersebut menyatakan bahwa Indonesia memiliki fokus untuk menyeimbangkan respon atas perkembangan lingkungan strategis yang ada dan akan berupaya untuk memajukan agenda nasional melalui kebijakan luar

\footnotetext{
${ }^{13}$ Arif Satriawan, "Kebijakan Indonesia Membuka Hubungan Diplomatik Dengan Negara - Negara Kawasan Pasifik (Tuvalu, Nauru, Kiribati)", JOM FISIP Vol. 3 No.2, Universitas Riau, Riau, 2016. Hlm. 2.

${ }^{14}$ Mohammad Hatta, "Mendajung Antara Dua Karang”, Pidato dalam sidang B.N.P.K.N.P, 1948. Hlm. 9.

${ }^{15}$ Graham T Allison, Op Cit. Hlm 707.

${ }^{16}$ Stephen Martin Walt, Op Cit, Ibid.
} 
negeri ${ }^{17}$ yang ditetapkan, diantaranya adalah untuk memperkuat integritas wilayah dan sentralitas Indonesia dalam perdamaian dan keamanan di kawasan ${ }^{18}$. perlu digaris bawahi pula bahwa menyelenggarakan perumusan dan pelaksanaan kebijakan di bidang penyelengaraan hubungan luar negeri dan politik luar negeri pada lingkup bilateral, intrakawasan dan antarkawasan di Asia Pasifik dan Afrika ${ }^{19}$ merupakan tugas utama dari biro tersebut. disini penulis melihat kesamaan kepentingan yang ditunjukan oleh Menlu Indonesia Retno Marsudi yang menyatakan pentingnya peningkatan peran Indonesia ${ }^{20}$.

Indonesia sangat berkepentingan dengan terpeliharanya stabilitas dan momentum pertumbuhan kawasan pasifik karena, lebih dari 25\% total nilai perdagangan Indonesia berasal dari Pasifik. Kawasan ini juga menyumbangkan Foreign Direct Investment (FDI) dan wisatawan yang tidak sedikit bagi Indonesia. Faktor Geografis yang berdekatan juga membuat Indonesia memiliki urgensi untuk memastikan terpeliharanya lingkungan politik dan keamanan yang kondusif dengan kawasan Pasifik, dan untuk itulah Indonesia harus bisa menghadapi pengawasan regional atas dugaan pelanggaran hak asasi manusia di Papua Barat ${ }^{21}$ untuk mewujudkan lingkungan politik yang kondusif tersebut.

\section{Hubungan Indonesia dan Negara-Negara Pasifik}

Hubungan Indonesia dengan negara - negara kepulauan di Pasifik bisa diangap terus mengalami perkembangan positif seiring berjalannya waktu. Secara historis hubungan Indonesia dengan kawasan pasifik telah dilakukan sejak tahun 70an dan ditandai pembukaan hubungan diplomatik dengan Kepulauan Fiji. Secara total Indonesia telah memiliki hubungan diplomatik 12 negara pasifik, yaitu: Fiji,

\footnotetext{
17 ___ "Laporan Kinerja Direktorat Asia Pasifik dan Afrika Tahun 2017”, Kementerian Luar Negeri Indonesia, Jakarta, 2018. Hlm. i.

18 Ibid.

${ }^{19}$ Peraturan Menteri Luar Negeri Republik Indonesia Nomor 2 Tahun 2016 tentang Organisasi dan Tata Kerja Kementerian Luar Negeri, Bab IV Pasal 152.

20 __ "Indonesian FM Presents the Diplomacy Priorities 2019-2024 to the House of Representatives", Op Cit. Ibid.

${ }^{21}$ Mackenzie Smith \& Johnny Blades, Op Cit. Ibid.
} 
Kiribati, Marshall Islands, Federasi Mikronesia, Nauru, Palau, Papua Nugini, Samoa, Solomon Islands, Tonga, Tuvalu, dan Vanuatu ${ }^{22}$.

Indonesia dan negara - negara Kawasan Pasifik yang terbagi menjadi tiga sub kawasan yaitu Melanesia, Polinesia, dan Mikronesia ${ }^{23}$ berbagi kesamaan yang tidak sedikit, selain sebagai negara kepulauan dan negara yang tergolong sebagai negara berkembang. Kesamaan akar budaya dan Ras antara masyarakat Pasifik khususnya Melanesia dengan masyarakat yang berasal dari Indonesia timur ${ }^{24}$ membuat adanya ikatan yang kuat. Namun justru hal inilah yang terkadang menimbulkan perbedaan persepsi. Perselisihan yang jelas tentu tercermin dari tudingan secara terbuka Vanuatu dan Kepulauan Solomon kepada Indonesia di forum PBB. Langkah tersebut tentu mewakili opini publik dari negara - negara tersebut yang menganggap bahwa informasi dari kelompok hak asasi manusia / Human Rights Watch yang memperkirakan puluhan ribu orang terlantar akibat kekerasan yang dilakukan militer Indonesia dalam upayanya untuk melawan kelompok separatis Papua yang bahkan masih berlangsung hingga saat ini.

Tindakan kedua negara tersebut juga jelas menjadi pembuktian dari keyakinan Walt bahwa dalam demokrasi dimana alur informasi dapat secara mudah diakses, kebijakan luar negeri bukan hanya produk dari visi pemimpin. Namun juga dibentuk oleh kekuatan-kekuatan yang bersaing dalam masyarakat $\operatorname{sipil}^{25}$ dalam hal ini merujuk kepada Kelompok hak asasi manusia yang berhasil membentuk opini publik baik domestik maupun internasional dan mendorong adanya aksi perlawanan dari masyarakat intra dan internasional terhadap kebijakan domestik Indonesia dalam penanganan isu tersebut, tentu semua kritikan tersebut muncul didasari dengan nilai - nilai kemanusiaan.

\footnotetext{
${ }^{22}$ Arif Satriawan, Op Cit. Hlm. 6.

23 Admin, "Peningkatan Hubungan Dengan Negara - Negara Kepulauan Pasifik", Tabloid Diplomasi. Org, diakses dari http://www.tabloiddiplomasi.org/peningkatan-hubungan${ }^{24}$ Ibid. dengan-negara-negara-kepulauan-pasifik/, pada tanggal 2 Januari 2019 pukul. 03.25 WIB.

${ }^{25}$ Stephen Martin Walt, Op Cit, Ibid.
} 


\section{E. Kebijakan Indonesia di Papua: Keputusan Sadar yang Menuai Kecaman}

Setiap negara tentu akan bertindak untuk melindungi kepentingan mereka masing - masing. Begitupun Indonesia yang mengambil keputusan untuk memberantas gerakan separatis yang muncul di Papua dengan pendekatan militer, keputusan tersebut tentu dilandasi dengan kepentingan utama untuk menjaga kedaulatan wilayah yang dimiliki. Sejak pergerakan separatis tersebut menguat dan menjatuhkan korban jiwa pada akhir tahun 2018, Menteri Menteri Koordinator Bidang Politik, Hukum, dan Keamanan (Menkopolhukam) Wiranto yang saat itu masih menjabat menyatakan bahwa pemerintah tidak berminat pada perundingan atau berkompromi dengan kelompok separatis di Papua ${ }^{26}$. Tentu jika mengacu kepada pemikiran Allison yang menyatakan bahwa terdapat banyak masalah yang timbul dan memaksa aktor intra-nasional untuk membereskan masalah tersebut dengan cepat, maka dapat dipastikan bahwa jalan keluar yang diambil tak jarang akan hanya disesuaikan dengan persyaratan aktor itu sendiri ${ }^{27}$, maka keputusan yang diambil oleh Menkopolhukam tersebut merupakan sesuatu yang wajar adanya. Pengambilan keputussan tersebut juga tentunya memperkuat argumen Walt yang menyatakan bahwa kejadian yang menimpa kebijakan suatu negara dalam hal ini protes yang dituai oleh pemerintahan Indonesia dari banyak pihak adalah benar merupakan hasil dari pilihan sadar daripada tindakan takdir yang tidak dapat $\operatorname{diduga}^{28}$.

Walt berkeyakinan bahwa dampak masyarakat sipil (Opini Publik) akan sangat besar dalam negara demokrasi ${ }^{29}$ seperti Indonesia. Jaminan kebebasan untuk berbicara dan berserikat, dan sikap ambivalen (bercabang dan bertentangan) terhadap kekuatan yang sifatnya terpusat akan mendorong kekuatan tersebut untuk bertindak sesuai keinginan publik atau sesuai dengan tekanan yang diberikan

\footnotetext{
${ }^{26}$ Pijar Anugerah, "Pemerintah Indonesia 'tidak akan berkompromi' dengan kelompok separatis Papua", BBC.com, diakses dari https://www.bbc.com/indonesia/indonesia-46588755, pada tanggal 2 Januari 2019 pukul. 13.03 WIB.

${ }^{27}$ Graham T Allison, Op Cit. Hlm 707.

${ }^{28}$ Stephen Martin Walt, Op Cit, Ibid.

${ }^{29}$ Ibid.
} 
publik. Namun nyatanya, demonstrasi yang terjadi di beberapa daerah di Papua ${ }^{30}$ yang disusul pula oleh aksi di wilayah lainnya di Indonesia ${ }^{31}$, serta kecaman dari banyak negara khusunya negara - negara Pasifik tidak membuat preferensi Indonesia dalam menangani isu ini berubah. Disini penulis melihat bahwa justru keyakinan Allison yang terbukti benar poin yang ia sampaikan mengenai rantai komando yang ada didalam negara membuat akan membersihkan dibersihkan melalui saluran yang mapan ${ }^{32}$ dan pada akhirnya opini publik disini menjadi tidak lagi penting karena ikut pula tersaring oleh saluran aksi / Action Channel yang telah mapan didalam kerangka negara tersebut yang jika dijabarkan melibatkan banyak pihak diantaranya Menteri, Dinas Militer, Pemerintah Daerah dan Pusat.

Secara lebih eksplisit reaksi negara - negara kawasan Pasifik dapat dianggap sebagai tindakan reaktif dari terjadinya marjinalisasi dari etnis Papua. Di level domestik saja reaksi yang ditunjukan oleh masyarakat dengan memberikan dukungan pasca kejadian kriminalisasi dan maraknya diskriminasi ${ }^{33}$ terhadap etnis tersebut, menurut penulis justru ibarat dua sisi mata uang. Disatu sisi merupakan sebuah bentuk kepeduliaan, namun disisi lain juga merupakan pengakuan dari publik domestik terhadap adanya praktik - praktik yang menyalahi nilai - nilai kemanusiaan yang dilakukan pemerintah. Dalam permasalahan tersebut penulis menyetujui pemikiran Allison yang menyatakan bahwa konsep kebijakan yang keamanan nasional akan menjadi hasil politik yang bertentangan dengan citra pemerintah di mata publik ${ }^{34}$, selain itu pernyataan Walt bahwa birokrasi urusan luar

30 Samsul Bahri Sembiring, "Salah Penanganan Papua akan Memperkuat Separatisme", Kompasiana.com, diakses

dari https://www.kompasiana.com/sbsembiring/5d78b874097f365c7634e962/salah-

penanganan-papua-akan-memperkuat-separatisme?page=all, pada tanggal 2 Januari 2019 pukul. 13.56 WIB.

31 Yudha Satriawan, "Aksi Grafiti di Solo Terkait Kasus Papua Picu Kekhawatiran Provokasi”, VoAIndonesia.com, diakses dari https://www.voaindonesia.com/a/aksi-grafiti-di-soloterkait-kasus-papua-picu-kekhawatiran-provokasi-/5063016.html, pada tanggal 2 Januari 2019 pukul. 14.15 WIB.

${ }^{32}$ Graham T Allison, Op Cit. Hlm 710.

${ }^{33}$ Callistasia Wijaya dan Heyder Affan, "Mahasiswa Papua bicara soal rasialisme: 'Ih kalian bau' dan tudingan tukang minum", BBC.com, diakses dari https://www.bbc.com/indonesia/indonesia-49430257, pada tanggal 5 Januari 2019 pukul. 21.49 WIB.

${ }^{34}$ Graham T Allison, Op Cit. Hlm 708. 
negeri secara tidak langsung akan melemahkan akuntabilitas dan menyulitkan proses check and balance $e^{35}$.

\section{F. Penetapan Kebijakan Luar Negeri Untuk Menginisiasi The Pacific Exposition 2019}

Pembentukan kebijakan luar negeri yang sesuai dengan kepentingan Indonesia dalam hubungannya dengan komunitas internasional tentu menjadi agenda penting yang harus dipersiapkan Indonesia. Menanggapi reaksi negatif yang diberikan oleh negara-negara pasifik atas isu kemanusiaan di Papua, maka peningkatan hubungan diplomatik Indonesia dengan negara-negara kawasan tersebut merupakan suatu urgensi. Meskipun memiliki kapasitas yang lebih besar dibanding negara - negara pasifik, Kemenlu tidak melakukan pendekatan dengan strategi konfrontatif dan tetap bertahan pada pilihan kebijakan luar negeri yang bersifat Concordance strategy (memberi keuntungan bersama) ${ }^{36}$. Pendekatan tersebut selain untuk memperbaiki citra hubungan yang baik tentu akan menguntungkan Indonesia, khususnya wilayah bagian Timur dalam proses mengejar ketertinggalan dalam berbagai sektor termasuk sumber daya manusia (SDM) di dalamnya ${ }^{37}$. Merujuk kepada penjelasan di bagian sebelumnya mengenai vitalnya peran negara kawasan Pasifik bagi Indonesia, tidak heran apabila Indonesia terdorong untuk menginisiasi The Pacific Exposition 2019 yang diadakan oleh kedutaan besar Indonesia di Selandia Baru ${ }^{38}$.

Pacific Exposition menjadi suatu acara yang diprioritaskan Indonesia untuk menetralisir usaha internasionalisasi isu Papua yang dilakukan oleh United Liberation Movement for West Papua (ULMWP) / Gerakan Persatuan Pembebasan

\footnotetext{
${ }^{35}$ Stephen Martin Walt, Op Cit, Ibid.

${ }^{36}$ John P. Lovel, "Foreign Policy in Perspective: Strategy, Adaptation, Decision Making.", Holt, Rinehart and Winston, Inc., New York, 1970. Hlm. 98-101.

${ }^{37}$ Michelle Natalia, "Hubungan Diplomatik RI-Pasifik Akan Genjot Kemajuan Indonesia Timur", SINDOnews.com, diakses dari https://ekbis.sindonews.com/read/1415662/33/hubungandiplomatik-ri-pasifik-akan-genjot-kemajuan-indonesia-timur-1561712997, pada tanggal 2 Januari 2019 pukul. 14.31 WIB.

${ }^{38}$ Mackenzie Smith \& Johnny Blades, Op Cit. Ibid.
} 
Papua Barat yang mengklaim sebagai kendaraan politik seluruh rakyat Papua ${ }^{39}$. Indonesia bukanlah negara pertama yang menyusun judul acara menarik dalam upayanya untuk menciptakan pengaruh di kawasan Pasifik jauh sebelum Pacific Exposition. Selandia Baru memiliki Reset, Australia memiliki Step Up, sementara Inggris juga menunjukan acara serupa dengan nama Uplift $^{40}$. Dalam pandangan teori birokrasi politik sudah jelas bahwa langkah ini merupakan langkah yang memiliki proposisi (keadaan yang belum tentu benar atau salah) khusus atau spesifik $^{41}$, dalam hal ini penulis melihat bahwa proposisi tersebut bersifat Partikular Negatif $^{42}$ (menyatakan tidak adanya hubungan) yang dimaksudkan untuk menunjukan bahwa Indonesia tidak berkaitan dengan dugaan pelanggaran yang diarahkan oleh negara-negara pasifik dalam isu Papua, upaya ini juga diharapkan menimbulkan efek Deterrence (pencegahan) terhadap intervensi lebih jauh dari negara - negara tersebut.

Disini terlihat jelas peran Menlu serta Kemenlu yang menjadi eksekutor dari kebijakan ini amatlah besar. Politik birokrasi di pemerintahan yang tidak lepas dari tuntutan beragam dari setiap aktor ${ }^{43}$ (individu maupun biro lainnya) nyatanya tidak sedikitpun mempengaruhi kebijakan biro tersebut dan menunjukan bahwa meskipun Menlu memiliki posisi sebagai Indians didalam struktur birokrasi yang ada, namun beliau memiliki kekuatan tawar yang cukup untuk mengatasi tekanan dari biro lainnya. Sementara itu dari sudut pandang lain keyakinan Walt bahwa pemisahan formal kekuasaan dan proses check and balance akan menyulitkan para pemimpin dalam hal ini Menlu, untuk menggunakan kekuasaannya sesuai dengan preferensi yang dimiliki ${ }^{44}$ tanpa mempertimbangkan pendapat publik pada akhirnya terbantahkan. Sebagai pembuktian argumen tersebut mari melihat opini yang

\footnotetext{
${ }^{39}$ Rohmatin Bonasir, “Upaya internasionalisasi Papua: 'Negara-negara anggota PBB lebih banyak dengar suara pemerintah Indonesia", BBC.com, diakses dari https://www.bbc.com/indonesia/indonesia-50498660, pada tanggal 2 Januari 2019 pukul. 14.54 WIB.

${ }^{40}$ Mackenzie Smith \& Johnny Blades, Op Cit. Ibid.

${ }^{41}$ Stephen Martin Walt, Op Cit, Ibid.

${ }^{42}$ Samhis Setiawan, “"Proposisi” Pengertian \& (Jenis - Bentuk - Contoh)”, Gurupendidikan.co.id, diakses dari https://www.gurupendidikan.co.id/proposisi-pengertian-jenis-bentuk-contoh, pada tanggal 2 Januari 2019 pukul. 18.31 WIB.

${ }^{43}$ Graham T Allison, Op Cit. Hlm 710.

${ }^{44}$ Stephen Martin Walt, Op Cit, Ibid.
} 
disampaikan oleh peneliti senior di Human Rights Watch Andreas Harsono (dalam keyakinan Walt termasuk kedalam komunitas kebijakan) yang menyatakan bahwa upaya Indonesia untuk melobi negara - negara Pasifik, tidak akan berhasil tanpa upaya internal dari negara - negara tersebut untuk menenangkan rakyat mereka sendiri ${ }^{45}$ tidak sama sekali dijadikan pertimbangan oleh Kemenlu. Padahal jelas pandangan tersebut menunjukan keraguan terhadap efektifitas Pacific Exposition sebagai badan baru yang digunakan untuk memajukan agenda politik Indonesia.

Mencermati kritik yang muncul dari perwakilan publik tersebut, penulis melihat bahwa keraguan tersebut memang beralasan. Sebagai bukti pada tahun 2015 senilai US\$2 juta ${ }^{46}$ tidak menyurutkan niat dari negara tersebut untuk bertindak berseberangan dengan Indonesia dalam penanganan permasalahan. Tercatat negara ini telah beberapa kali mengganggu integritas kedaulatan Indonesia terlepas dari bantuan yang telah disalurkan tersebut. pada 2017 Vanuatu menjadi salah satu negara yang mengikuti gelaran pertemuan di Brussels untuk membahas nasib Papua Barat yang tentu merupakan sebuah intervensi bagi Indonesia, kemudian di 2018 negara ini juga menuduh Indonesia melanggar Hak Asasi Manusia di Papua di forum internasional ${ }^{47}$. Menurut penulis disini terlihat bahwa kebebasan yang didapat oleh warga negara atau masyarakat lainnya terhadap akses informasi akan memberikan mereka keleluasaan dalam memberikan pendapat dan membentuk pasar ide ${ }^{48}$ merupakan sesuatu yang validitasnya teruji.

Penulis melihat bahwa prioritas, persepsi, dan cara penanganan masalah ${ }^{49}$ yang telah dirumuskan secara jelas sebelumnya didalam formulasi $4+1$ tetap

${ }^{45}$ Nivell Rayda, "Indonesia Bantah Indo AID Bertujuan Redam Dukungan Kemerdekaan Papua", Matamatapolitik.com, diakses dari https://www.matamatapolitik.com/indonesia-bantahperan-indo-aid-untuk-redam-dukungan-kemerdekaan-papua-in-depth, pada tanggal 2 Januari 2019 pukul. 19.40 WIB.

${ }^{46}$ Ike Agestu, "Indonesia Kirim Bantuan Senilai Rp25,7 M ke Vanuatu", CNNIndonesia.com, diakses dari https://www.cnnindonesia.com/internasional/20150404150713-11344161/indonesia-kirim-bantuan-senilai-rp257-m-ke-vanuatu, pada tanggal 5 Januari 2019 pukul. 10.53 WIB.

47 Muhaimin, "Potret Vanuatu, Negara yang Kerap Ikut Campur Urusan Indonesia", Sindonews.com, diakses dari https://international.sindonews.com/read/1375269/40/potretvanuatu-negara-yang-kerap-ikut-campur-urusan-indonesia-1548983109, pada tanggal 5 Januari 2019 pukul. 11.00 WIB.

${ }^{48}$ Stephen Martin Walt, Op Cit, Ibid.

${ }^{49}$ Graham T Allison, Op Cit. Hlm 709. 
menjadi acuan dari penetapan kebijakan yang diambil, terlepas dari berapapun biaya dari pengadaan ${ }^{50}$ yang diperlukan untuk menjalankan kebijakan inisiasi Pacific Exposition ini. Penulis meyakini bahwa Indonesia mengeluarkan biaya yang tidak sedikit untuk mendorong forum multilateral ini untuk bisa diadakan apalagi di wilayah kedaulatan negara lain yaitu Selandia Baru. Sebagai perbandingan, program Reset yang diusung oleh Selandia Baru menghabiskan dana yang berada dikisaran US\$ 150 juta $^{51}$. Publik sebenarnya mempertanyakan penggunaan dana sebesar itu yang murni dipersiapkan untuk hal yang menurut mereka tidak jelas definisinya, apakah untuk Soft Diplomacy atau diplomasi publik. Jelas publik Selandia Baru menginginkan bahwa dana tersebut dapat digunakan secara efektif dan bukan hanya sekedar ajang pamer pemerintahan di kawasan pasifik ${ }^{52}$. Sekali lagi klaim Alison bahwa analisis akan menghasilkan rekomendasi yang bertentangan $^{53}$ sesuai dengan apa yang terjadi namun pada akhirnya The Ministry of Foreign Affairs and Trade's (MFAT) Selandia Baru tetap mengeksekusi program tersebut. Jelas disini kembali terlihat kemampuan aktor yang dalam hal ini merujuk kepada Menlu dan biro yang dikepalai memiliki pengaruh yang kuat dan menghasilkan kesuksesan dalam proses penetapan kebijakan luar negeri tersebut. Peran opini publik menjadi amat minim dalam proses tersebut akibat ketiadaan kelompok pribadi dan individu yang memberikan dukungan keuangan ke pemerintahan karena memang mereka tidak memiliki tujuan khusus dalam kebijakan luar negeri ${ }^{54}$ yang diambil tersebut.

\section{G. The Pacific Exposition 2019 Pertaruhan Reputasi \& Solusi Sang Menteri}

Prioritas Indonesia untuk membuat citra positif melalui jalan diplomasi, menggerakkan Indonesia sejalan dengan kekuatan Barat lain yang juga berusaha

\footnotetext{
50 Ibid.

${ }^{51}$ Simon Mark, "New Zealand's Pacific reset: the case for cultural diplomacy", Stuff.co.nz, diakses dari https://www.stuff.co.nz/national/politics/opinion/106227005/new-zealands-pacific52 Ibid. reset-the-case-for-cultural-diplomacy, pada tanggal 5 Januari 2019 pukul. 14.04 WIB.

${ }^{53}$ Graham T Allison, Op Cit. Hlm. 707.

${ }^{54}$ Stephen Martin Walt, Op Cit, Ibid.
} 
meningkatkan keterlibatan mereka. Kegiatan ini menjadi tempat bagi beberapa pejabat tingkat tinggi dari seluruh Pasifik, termasuk Menlu Selandia Baru, Australia, dan Indonesia. Menlu Indonesia Retno Marsudi berujar bahwa kegiatan ini bisa dianggap sebagai momentum "Kebangkitan Pasifik" 55. Di kesempatan yang sama terucap pula narasi bahwa wajah-wajah Polinesia dan Melanesia merupakan wajah yang familiar dan tidak asing di Indonesia. Disini jelas terlihat bahwa Menlu Indonesia mencoba untuk menetralisir kondisi dengan menciptakan citra baik Indonesia terhadap masyarakat yang berasal dari Papua. Fakta bahwa dalam politik birokrasi setiap hasil keputusan akan memiliki konsekuensi ${ }^{56}$ tentu membuat Menlu berusaha sebaik untuk melakukan segala cara bukan hanya untuk mensukseskan kebijakan tersebut, namun juga demi kepentingan pribadinya untuk menjaga reputasi yang dimiliki.

Untuk lebih memperkuat argumen mengenai reputasi, fakta bahwa pertemuan ini juga akan dihadiri oleh sejumlah menteri Indonesia dan anggota dari Dewan Perwakilan Rakyat Republik Indonesia (DPR-RI) ${ }^{57}$ menjadikan klaim yang diutarakan oleh Allison Valid. Klaim bahwa pada akhirnya setiap aktor akan mengikuti laju permainan birokrasi dan memaksa mereka untuk mendapatkan perhatian pihak lain dengan tujuan untuk meyakinkan mereka ${ }^{58}$ adalah sesuatu yang benar adanya. Dengan menunjukan keberhasilan dalam pelaksanaan kebijakan ini sudah pasti bahwa Menlu, Kemenlu, dan seluruh pihak yang terkait dengan biro tersebut akan mendapatkan perhatian dari pihak lainnya. Hasil positif memang dituai oleh biro tersebut, Fadli Zon yang merupakan Wakil Ketua DPR RI menyampaikan Apresiasi besar atas berlangsungnya event ini ${ }^{59}$. Menariknya

\footnotetext{
${ }^{55}$ Mackenzie Smith, “Indonesia's 'Pacific Elevation': Step up or power play?”, Rnz.co.nz, diakses dari https://www.rnz.co.nz/international/pacific-news/394434/indonesia-s-pacificelevation-step-up-or-power-play, pada tanggal 2 Januari 2019 pukul. $19.40 \mathrm{WIB}$.

${ }^{56}$ Graham T Allison, Op Cit. Hlm 710.

57 __ "Sетиа Berawal dari Persahabatan: Melalui Pacific Exposition 2019, RI Ciptakan Momentum Pasifik", diakses dari https://kemlu.go.id/portal/id/read/450/berita/semuaberawal-dari-persahabatan-melalui-pacific-exposition-2019-ri-ciptakan-momentumpasifik, pada tanggal 3 Januari 2019 pukul. 23.08 WIB.

${ }^{58}$ Graham T Allison, Op Cit. Ibid.

${ }^{59}$ Gede Moenanto, "Fadli Zon Ungkap Pentingnya PACIFIC EXPOSITION untuk Menegaskan Kehadiran Indonesia di Pasifik", Wartakota.Tribunews.com, diakses dari https://wartakota.tribunnews.com/2019/07/14/fadli-zon-ungkap-pentingnya-pacific-
} 
keterlibatan dari aktor lain ini secara nyata menunjukan bahwa dalam klaim di dalam politik birokrasi tidak ada aktor yang menyatu namun sebagai pemain tunggal $^{60}$ adalah benar. Pernyataan Fadli jelas merupakan apresiasi terbatas yang diberikan pada aktor atau biro yang menyelenggarakan saja, bukan sebagai pencapaian pemerintah secara keseluruhan atau bukan sebagai pencapaian satu kesatuan meskipun apresiasi positif yang diberikan oleh Winston Peters dan Marise Payne $^{61}$ menunjukan bahwa Indonesia dianggap sebagai kesatuan.

Dalam Pelaksanaan Pacific Exposition di Auckland, Selandia Baru. Menlu Retno Marsudi juga melakukan banyak pertemuan antar negara ${ }^{62}$ yang dari sudut pandang birokrasi politik maka langkah ini bisa dianggap sebagai cara dari Menlu untuk membangun koalisi dari kekuatan yang relevan yang ada ${ }^{63}$ khususnya dalam interaksi Indonesia dengan negara - negara di kawasan Pasifik. Jika dirinci maka Menlu Retno telah bertatap muka dengan perdana menteri dan menteri dari Australia, Kepulauan Cook, Kepulauan Solomon, Niue, Papua Nugini, Selandia Baru, Tuvalu dan Kiribati ${ }^{64}$. Keberhasilan Menlu tersebut jelas menjadi bantahan dari keyakinan Walt bahwa visi optimis hanya merupakan ilusi ${ }^{65}$ karena ternyata terbukti Pacific Exposition bisa menjadi solusi tepat dalam menangani isu ketegangan yang ada.

Pembukaan hubungan diplomatik secara resmi dengan dua negara pasifik yaitu Kepulauan Cook dan Niue yang dilangsungkan di sela penyelenggaraan Pacific Exposition ${ }^{66}$ tentu menjadi keberhasilan lain yang berhasil dicetak oleh Kemenlu. Namun, keberhasilan ini juga seolah membuktikan bahwa argumen Walt

exposition-untuk-menegaskan-kehadiran-indonesia-di-pasifik, pada tanggal 3 Januari 2019 pukul. 23.21 WIB.

${ }^{60}$ Graham T Allison, Op Cit. Hlm. 707.

${ }^{61}$ Valerie Dante, Op Cit. Ibid.

${ }^{62}$ Valerie Dante, "Di Pacific Exposition 2019, RI bangun persahabatan dengan sejumlah negara”, Alinea.id, diakses dari https://www.alinea.id/dunia/di-pacific-exposition-2019-ri-bangunpersahabatan-b1Xjt917n, pada tanggal 3 Januari 2019 pukul. 23.53 WIB.

${ }^{63}$ Graham T Allison, Op Cit. Hlm 711.

${ }^{64}$ Ibid.

65 Stephen Martin Walt, Op Cit, Ibid.

${ }^{66}$ Rahman Asmardika, "Indonesia Resmi Buka Hubungan Diplomatik dengan Kepulauan Cook dan Niue", News.okezone.com, diakses dari https://news.okezone.com/read/2019/07/13/18/2078404/indonesia-resmi-buka-hubungandiplomatik-dengan-kepulauan-cook-dan-niue, pada tanggal 4 Januari 2019 pukul. 00.21 WIB. 
yang menyatakan bahwa elit kebijakan luar negeri (Menlu dan Kementerian) tidak terbatasi oleh publik yang berpengetahuan luas yang juga memiliki kebutuhan untuk menetapkan prioritas dan meminta pertanggungjawaban ${ }^{67}$ dalam proses penetapan aksi politik mereka. Sudah jelas dari pemaparan di bagian sebelumnya bahwa publik sebenarnya lebih menginginkan penyelesaian dan pertanggungjawaban terhadap isu yang terjadi didalam negeri dan forum seperti ini tidak terlalu dibutuhkan saat ini karena tidak akan efektif ${ }^{68}$. Namun terlepas dari anggapan tersebut kebijakan ini bagi penulis menjadi suatu jalan bagi Menlu yang bisa disebut sebagai Indian dalam teori birokrasi untuk mengatasi masalah dan merupakan kebijakan yang menjadi produk dari proses interaksi dan penyesuaian dari berbagai individu dan organisasi ${ }^{69}$ sebagai solusi terhadap permasalahan yang dihadapi dengan negara - negara di kawasan Pasifik.

\section{KESIMPULAN}

Dari seluruh pembahasan diatas penulis mengambil kesimpulan bahwa teori birokrasi politik menjadi teori yang lebih dominan untuk mempelajari proses dari perumusan kebijakan luar negeri Indonesia untuk menginisiasi Pacific Exposition 2019. Peran Menlu Retno sebagai birokrat yang membawahi biro, jelas menjadi salah satu faktor penting dalam perumusan dan implementasi kebijakan ini meskipun mengesampingkan opini yang disampaikan publik. Pacific Exposition 2019 adalah solusi tepat untuk bereaksi terhadap tudingan pelanggaran dari negara di kawasan Pasifik, dan merupakan langkah pasti yang merupakan produk dari pola inferensi dominan ${ }^{70}$ yang ada dalam birokrasi politik Indonesia. Meskipun permasalahan ini tergolong pelik dan berhubungan dengan Keamanan nasional yang dalam pandangan Allison adalah suatu hal yang terlalu penting untuk diselesaikan oleh permainan politik ${ }^{71}$, namun keputusan ini merupakan keputusan yang sesuai dengan orientasi politik Indonesia.

\footnotetext{
${ }^{67}$ Stephen Martin Walt, Op Cit, Ibid.

${ }^{68}$ Nivell Rayda, Op Cit. Ibid.

${ }^{69}$ Graham T Allison, Op Cit. Ibid.

${ }^{70}$ Ibid. Hlm. 110.

${ }^{71}$ Graham T Allison, Op Cit. 709.
} 


\section{DAFTAR PUSTAKA}

. 2016. Peraturan Menteri Luar Negeri Republik Indonesia Nomor 2 tentang Organisasi dan Tata Kerja Kementerian Luar Negeri.

. 2018. Laporan Kinerja Direktorat Asia Pasifik dan Afrika Tahun 2017. Jakarta: Kementerian Luar Negeri Indonesia.

. 2019. Home. Pacific Exposition 2019 Official Website. RNZ.co.nz. http://pacificexposition.co.nz. Diakses 1 Januari 2020.

2019. Indonesian FM Presents the Diplomacy Priorities 2019-2024 to the House of Representatives. Ministry of Foreign Affairs of the Republic of Indonesia. https://kemlu.go.id/portal/en/read/786/berita/indonesian-fmpresents-the-diplomacy-priorities-2019-2024-to-the-house-ofrepresentatives. Diakses 1 Januari 2020.

2019. Semua Berawal dari Persahabatan: Melalui Pacific Exposition 2019, RI Ciptakan Momentum Pasifik. https://kemlu.go.id/portal/id/read/450/berita/semua-berawal-daripersahabatan-melalui-pacific-exposition-2019-ri-ciptakan-momentumpasifik. Diakses 3 Januari 2020.

Admin. 2019. Peningkatan Hubungan Dengan Negara - Negara Kepulauan Pasifik. Tabloid Diplomasi. http://www.tabloiddiplomasi.org/peningkatan-hubungan-dengan-negaranegara-kepulauan-pasifik. Diakses 2 Januari 2020.

Agestu, Ike. 2015. Indonesia Kirim Bantuan Senilai Rp25,7 M ke Vanuatu. CNNIndonesia.com. https://www.cnnindonesia.com/internasional/20150404150713-11344161/indonesia-kirim-bantuan-senilai-rp257-m-ke-vanuatu. Diakses 5 Januari 2019.

Allison, Graham T. 1969. Conceptual Models and 'The Cuban Missile Crisis'. The American Political Science Review, VOL. LXIII. Cambridge: Cambridge University Press.

Anugerah, Pijar. Pemerintah Indonesia 'tidak akan berkompromi' dengan kelompok separatis Papua. BBC.com. https://www.bbc.com/indonesia/indonesia46588755. Diakses 2 Januari 2020.

Asmardika, Rahman. 2019. Indonesia Resmi Buka Hubungan Diplomatik dengan Kepulauan Cook dan Niue. News.okezone.com. https://news.okezone.com/read/2019/07/13/18/2078404/indonesia-resmi- 
buka-hubungan-diplomatik-dengan-kepulauan-cook-dan-niue. Diakses 4 Januari 2020.

Bonasir, Rohmatin. 2019. Upaya internasionalisasi Papua: 'Negara-negara anggota PBB lebih banyak dengar suara pemerintah Indonesia'. BBC.com. https://www.bbc.com/indonesia/indonesia-50498660. Diakses 2 Januari 2020.

Dante, Valerie. 2019. Di Pacific Exposition 2019, RI bangun persahabatan dengan sejumlah negara. Alinea.id. https://www.alinea.id/dunia/di-pacificexposition-2019-ri-bangun-persahabatan-b1Xjt917n. Diakses 3 Januari 2020.

Dea. 2019. Vanuatu dan Kepulauan Solomon Bawa Isu Papua ke Dewan HAM $P B B$. CNN Indonesia.com. https://www.cnnindonesia.com/internasional/20190918150338-113431611/vanuatu-dan-kepulauan-solomon-bawa-isu-papua-ke-dewan-hampbb. Diakses 1 Januari 2020.

Hatta, Mohammad. 1948. Mendajung Antara Dua Karang. Pidato dalam sidang B.N.P.K.N.P.

Lovel, John P. 1970. Foreign Policy in Perspective: Strategy, Adaptation, Decision Making. New York: Holt, Rinehart and Winston, Inc.

Mark, Simon. New Zealand's Pacific reset: the case for cultural diplomacy. Stuff.co.nz. https://www.stuff.co.nz/national/politics/opinion/106227005/newzealands-pacific-reset-the-case-for-cultural-diplomacy. Diakses 5 Januari 2019.

Moenanto, Gede. 2019. Fadli Zon Ungkap Pentingnya PACIFIC EXPOSITION untuk Menegaskan Kehadiran Indonesia di Pasifik. Wartakota.Tribunews.com. https://wartakota.tribunnews.com/2019/07/14/fadli-zon-ungkappentingnya-pacific-exposition-untuk-menegaskan-kehadiran-indonesia-dipasifik. Diakses 3 Januari 2020.

Muhaimin. 2019. Potret Vanuatu, Negara yang Kerap Ikut Campur Urusan Indonesia. Sindonews.com. https://international.sindonews.com/read/1375269/40/potret-vanuatunegara-yang-kerap-ikut-campur-urusan-indonesia-1548983109. Diakses 5 Januari 2019.

Natalia, Michelle. 2019. Hubungan Diplomatik RI-Pasifik Akan Genjot Kemajuan Indonesia Timur. SINDOnews.com. https://ekbis.sindonews.com/read/1415662/33/hubungan-diplomatik-ri- 
pasifik-akan-genjot-kemajuan-indonesia-timur-1561712997. Diakses 2 Januari 2020.

Rayda, Nivell. 2019. Indonesia Bantah Indo AID Bertujuan Redam Dukungan Kemerdekaan Papua. Matamatapolitik.com. https://www.matamatapolitik.com/indonesia-bantah-peran-indo-aid-untukredam-dukungan-kemerdekaan-papua-in-depth. Diakses 2 Januari 2020.

Rosyidin, Mohamad. 2019. Gaya Diplomasi Jokowi dan Arah Politik Luar Negeri RI. Detiknews.com. https://news.detik.com/kolom/d-4740964/gayadiplomasi-jokowi-dan-arah-politik-luar-negeri-ri. Diakses 4 Januari 2020.

Satriawan, Arif. 2016. Kebijakan Indonesia Membuka Hubungan Diplomatik Dengan Negara - Negara Kawasan Pasifik (Tuvalu, Nauru, Kiribati). JOM FISIP Vol. 3 No.2. Riau: Universitas Riau.

Satriawan, Yudha. 2019. Aksi Grafiti di Solo Terkait Kasus Papua Picu Kekhawatiran Provokasi. VoAIndonesia.com. https://www.voaindonesia.com/a/aksi-grafiti-di-solo-terkait-kasus-papuapicu-kekhawatiran-provokasi-/5063016.html. Diakses 2 Januari 2020.

Sembiring, Samsul Bahri. 2019. Salah Penanganan Papua akan Memperkuat Separatisme. Kompasiana.com. diakses dari https://www.kompasiana.com/sbsembiring/5d78b874097f365c7634e962/s alah-penanganan-papua-akan-memperkuat-separatisme?page=all. Diakses 2 Januari 2020.

Setiawan, Samhis. 2019. "Proposisi" Pengertian \& (Jenis - Bentuk - Contoh). Gurupendidikan.co.id. https://www.gurupendidikan.co.id/proposisipengertian-jenis-bentuk-contoh. Diakses 2 Januari 2020.

Smith, Mackenzie \& Blades, Johnny. Indonesia to make major Pacific pitch at NZ expo. RNZ.co.nz. https://www.rnz.co.nz/international/pacificnews/393325/indonesia-to-make-major-pacific-pitch-at-nz-expo. Diakses 1 Januari 2020.

Smith, Mackenzie. 2019. Indonesia's 'Pacific Elevation': Step up or power play?. Rnz.co.nz. https://www.rnz.co.nz/international/pacificnews/394434/indonesia-s-pacific-elevation-step-up-or-power-play. Diakses 2 Januari 2020.

Utama, Abraham. 2019. Pemerintah Indonesia 'tak bisa' cegah negara Pasifik angkat Papua di PBB. BBC.com. https://www.bbc.com/indonesia/indonesia-41764268. Diakses 1 Januari 2020. 
Walt, Stephen Martin. 2018. Hell of Good Intention, America Foreign Policy Elite and The Decline of U.S. Primacy. New York: Farrar, Straus, and Giroux.

Wijaya, Callistasia dan Affan, Heyder. Mahasiswa Papua bicara soal rasialisme: 'Ih kalian bau' dan tudingan tukang minum. BBC.com. https://www.bbc.com/indonesia/indonesia-49430257. Diakses 5 Januari 2019. 